\title{
YIELD OF COCOA UNDER DIFFERENT AGROFORESTRY SYSTEMS IN A DRY TROPICAL FOREST IN WESTERN COLOMBIA
}

\author{
Carlos H. Escobar Ramírez ${ }^{1}$, Óscar de J. Córdoba-Gaona ${ }^{1}$, Guillermo A. Correa Londoño \\ y Enrique G. Martínez Bustamante ${ }^{1}$
}

\begin{abstract}
The expansion and modernization of the cocoa area under new strategies, such as the use of adapted genetic material and the establishment of Agroforestry Systems with cocoa, under criteria of competitiveness and sustainability, require selecting sites with adequate biophysical conditions, which facilitate the optimization of resources for production. In this sense, we conducted a study in the Estación Agraria Cotové, of the Universidad Nacional de Colombia, located in a tropical dry forest life zone (TDF), at 540 meters of elevation, with an average temperature of $27^{\circ} \mathrm{C}$, average annual precipitation annual of $1,031 \mathrm{~mm}$ and relative humidity less than $70 \%$. The yield components and productive potential of four cocoa clones, ICS 95, TSH565, CCN 51, and ICS 60 , were evaluated. The cocoa clones were planted under two controlled sunlight habitats, generated by the timber species Gmelina arborea Roxb. (single-row and double-row arrangement), and two different canopy management of the cocoa plants (plagiotropic and orthotropic growth stimulus). The clones TSH 565 and CCN 51 showed the highest yields in the two harvest years. ICS 95 showed the lowest bean index. Regarding the pod index, no differences were observed between the cocoa clones. Clones TSH 565 and CCN 51 stood out as the earliest and most productive clones.
\end{abstract}

Additional keywords: Drought stress, Gmelina arborea, Theobromoa cacao

\section{RESUMEN}

Rendimiento del cacao en diferentes sistemas agroforestales en un bosque seco tropical del occidente colombiano

La ampliación y modernización del área cacaotera, bajo nuevas estrategias, como la utilización de material genético sobresaliente y el establecimiento de Sistemas Agroforestales con cacao, bajo criterios de competitividad y sostenibilidad exigen la selección de sitios con adecuadas condiciones biofísicas, que faciliten la optimización de los recursos para la producción. Esta investigación se desarrolló en la Estación Agraria Cotové, de la Universidad Nacional de Colombia, ubicada en una zona de vida de bosque seco tropical (bs-T), a una altitud aproximada de $540 \mathrm{msnm}$., con temperatura promedio de $27^{\circ} \mathrm{C}$, precipitación media anual de 1.031 $\mathrm{mm}$ y humedad relativa menor al $70 \%$. Se evaluaron los componentes del rendimiento y potencial productivo de cuatro materiales genéticos de cacao (ICS 95, TSH565, CCN 51, ICS 60) dispuestos bajo dos hábitats lumínicos de la especie maderable Gmelina arborea Roxb. (hilera simple o hilera doble), sometidos a dos manejos diferentes de la copa del cacao (modificación de su arquitectura mediante el estímulo del crecimiento plagiotrópico u ortotrópico). Los clones de cacao TSH 565 y CCN 51 fueron los que presentaron los mayores rendimientos en los dos años de cosecha. ICS 95 mostró el índice de grano más bajo. En cuanto al índice de mazorca, no se observaron diferencias entre los clones de cacao. Los clones TSH 565 y CCN 51 se destacaron como clones precoces y de mayor producción.

Palabras clave adicionales: Déficit hídrico, Gmelina arborea, Theobromoa cacao

\section{INTRODUCTION}

Arid and semi-arid areas are considered to have limitations or deficits in the natural supply of water for several physical-biotic and socioeconomic processes (Pabón and Alarcón, 2016).
In Colombia, arid and semi-arid areas represent near $16-17 \%$ of the country's continental territory $\left(200000 \mathrm{~km}^{2}\right)$. The current influence of global warming has become one of the major concerns worldwide, considering that climate change in the economic sector has generated increases in the

Received: February 18, 2021

Accepted: November 11, 2021

${ }^{1}$ Facultad de Ciencias Agrarias, Universidad Nacional de Colombia, Sede Medellín. Colombia. e-mail: chescoba@unal.edu.co (corresponding author); ojcordobag@ unal.edu.co; gcorrea@unal.edu.co; enmartin@unal.edu.co 
frequency of extreme events such as floods, droughts and heatwaves (Fernández, 2013).

Climate change affects the areas where cocoa is grown for physiological reasons, mainly about water regimes affecting this crop; climatic drying would thus increase evapotranspiration resulting from an increase in temperature not compensated by annual rainfall (Cilas and Batisde, 2020). By modelling techniques, Ceccarelli et al. (2021) found that cocoa is expected to be vulnerable to climate change. Due to these circumstances, it is necessary to find strategies to mitigate climate change, which must be adopted to minimize the negative impacts on agricultural sectors and the slow down of agricultural yields. In such conditions, a lot of recent studies have aimed to limit climate change impacts. They have promoted the use of Agroforestry Systems (AFS) as a critical model in transforming conventional agriculture into Climate-Smart Agriculture as a way to buffer climate change impacts (FAO, 2010; Cilas and Batisde, 2020). According to Montagnini et al. (2015), as a helpful tool for climate change mitigation, AFS with proper management can have good carbon accumulation rates; likewise, they can avoid deforestation by supplying products on already deforested lands essential tool for reclamation programs. Agroforestry systems promote resistance for adaptation to climate variability with their diversification, reducing risks and allowing flexibility to change towards species or varieties adapted to new conditions.

The role of AFS in climate change depends mainly on design and management, including annual and perennial species under a shade (Montagnini et al., 2015). Some models have been developed in several countries, mainly as alternatives and strategies for mitigating impacts occurring in the face of climate change. Increases in temperatures and irregular rainfall become unfavorable conditions for production (Montagnini et al., 2015); therefore Schroth et al. (2009) suggest incorporating shade species into the cropping system as a strategy to maintain biodiversity, as well as to provide ecosystem services and protection against hurricanes. Considering that the TDF is one of the most threatened life zones due to the increase in deforestation, frontier agricultural expansion, and climate change, the AFS has become a productive alternative model to minimize these effects, seeking to protect strategic ecosystems. This AFS should allow the development of systems that guarantee adequate soil and water resource uses and species and arrangements that adapt to the life zone conditions where they are established or can be installed. It is essential to understand cocoa's eco-physiological relationships under different plantation arrangements associated with timber species and its adaptability to regions with scarce resources, mainly water (Niether et al., 2018). For this reason, this research aimed to generate information on the productive behavior of cocoa plants under two different controlled sunlight habitats by the melina species.

\section{MATERIALS AND METHODS}

Location. This research was carried out at the agricultural station Cotové (EA Cotové) of the Facultad de Ciencias Agrarias, Universidad Nacional de Colombia, located in El Espinal village, municipality of Santa Fe de Antioquia (6 ${ }^{\circ}$ $33^{\prime} \mathrm{N}, 77^{\circ} 04^{\prime} \mathrm{W}, 540 \mathrm{~m}$.a.s.l.). According to the Holdridge classification, the station is located in a TDF life zone, and during the conduction of the trials, the climatic variables were recorded. In total, $611 \mathrm{~mm}$ of precipitation was registered during the 20 months of the experiments, highlighting dry periods in July, August, and September 2014 and a dry season marked between November 2014 and April 2015, with a rainy season between May and October, which characterizes this locality as a unimodal distribution zone. The average minimum and maximum temperatures during the evaluation months were 27 and $29^{\circ} \mathrm{C}$, respectively, with 28 ${ }^{\circ} \mathrm{C}$ general average (Figure 1) (IDEAM, 2020).

Experimental area. The experimental plot consisted of a cocoa-melina agroforestry system in an area of 5 ha, established in 2009. Melina species (Gmelina arborea) was used as permanent shade and installed in two spatial arrangements: in a single row (SR) and double row (DR). Both SR and DR were planted in rows $21 \mathrm{~m}$ apart from each other, with $3 \mathrm{~m}$ between trees. Melina trees were planted in a triangle $(3 \times 3 \mathrm{~m})$ for a final density of 336 trees $\cdot \mathrm{ha}^{-1}$ in DR and 168 trees $\cdot \mathrm{ha}^{-1}$ in SR (Figure 2). Four clones of cocoa were established (ICS60, ICS95, TSH565, and CCN51), grafted on an IMC-67 rootstock and 
sown at a distance of $3 \mathrm{~m}$ in a triangle. Consequently, given that the forestry component's sowing density modified the cocoa population density, finally, in SR and DR arrangement, a total of 1,210 and 1,037 cocoa plants $\cdot \mathrm{ha}^{-1}$ were planted, respectively. The selected clones stand out in terms of productivity, resistance to diseases, sensory quality, and their potential use throughout the country (Montoya et al., 2015; Quintana et al., 2015). According to
Fedecacao (2012), CCN51 is an auto-compatible clone, inter-compatible with TSH565 and interincompatible with ICS60 and ICS95. The clone SH565 is auto incompatible, inter-compatible with CCN51 and ICS95, and inter-incompatible with ICS60. ICS95 is self-compatible, interincompatible with CCN51 and ICS60, and intercompatible with TSH565. ICS60 is selfincompatible, inter-compatible with CCN51, TSH565, and ICS95.

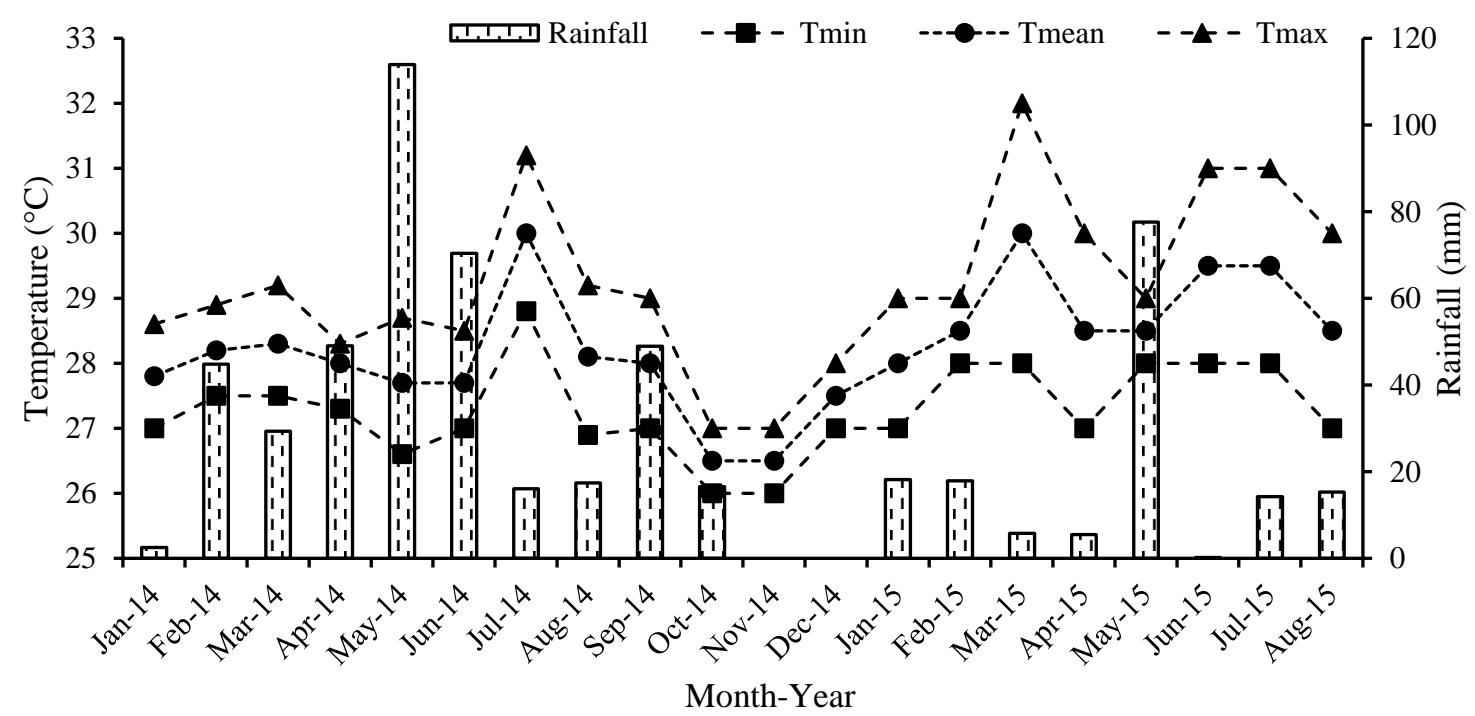

Figure 1. Monthly rainfall and minimum, mean, and maximum monthly temperatures were recorded between January 2014 and August 2015 at EA Cotové. Universidad Nacional de Colombia. Santa Fe de Antioquia, Colombia. (years 2013-2015)

The soil used in the experiment was a claysandy-loam textural class, $6.9 \mathrm{pH}, 0.30 \mathrm{dS} \cdot \mathrm{m}^{-1}$ electric conductivity, and $5.4 \%$ organic matter. In cmolc $\cdot \mathrm{kg}^{-1} 25.79$ cation exchange capacity, 16.54 $\mathrm{Ca}, 9.59 \mathrm{Mg}, 0.40 \mathrm{~K}$ and $0.20 \mathrm{Na}$. In $\mathrm{mg} \cdot \mathrm{kg}^{-1} 29.4$ $\mathrm{P}, 4.4 \mathrm{~S}, 12.0 \mathrm{Fe}, 1.7 \mathrm{Mn}, 1.5 \mathrm{Zn}, 2.8 \mathrm{Cu}$, and 0.34 B. Based on the soil condition, annual fertilization in $\mathrm{kg}$. ha was applied using $366 \mathrm{~N}, 75 \mathrm{P}_{2} \mathrm{O}_{5}, 376$ $\mathrm{K}_{2} \mathrm{O}, 48 \mathrm{MgO}, 108 \mathrm{CaO}$, and $29 \mathrm{~S}$. The crop irrigation was carried out with flood irrigation, applying $14 \mathrm{~mm}$ of irrigation level every fifteen days in the months with less than $20 \mathrm{~mm}$ rainfall (Figure 2).

Experimental design. A randomized complete block design with four repetitions was used. In the treatment arrangement, a subdivided plot design was used with the combinations of levels of the habitat $(\mathrm{H})$ and pruning $(\mathrm{P})$ factors $(2 \times 2)$ in whole plots and clone factor (C) in split plots. The habitat factor referred to the type of agroforestry arrangement and was made up of two levels: single row (SR) and double-row (DR) planting, which modified the number of cacao plants per ha. The pruning factor referred to the growth that was obtained by pruning and was made up of plagiotropic growth (PG) and orthotropic growth (OG) levels. Plagiotropic growth stimulus consisted of developing five main branches for each tree, which were selected for their vigor, distribution in the tree, and the angle of insertion of them to the horizontal, which oscillated between $15^{\circ}$ and $45^{\circ}$. Orthotropic growth stimulus consisted of the induction and development of three main branches for each tree, with the same selection criteria similar to plagiotropic management, with a difference in the angle of insertion of the branches between 45 and $80^{\circ}$. The clone factor was made up of four cocoa clones 
(CCN51, TSH565, ISC60, and ISC 95).

Recorded variables. Total dry cocoa production $\left(\mathrm{kg} \cdot \mathrm{ha}^{-1}\right)$ was quantified during two production cycles: year 1 (2014) and year 2 (2015), with weekly harvests in the production peaks and fortnightly in the periods of less production. The response of the four cocoa clones was evaluated; two were self-compatible (ICS95 and CCN51) and two self-incompatible materials (TSH565 and ICS60). The yield components, cocoa pod index (PI), and bean index (BI) were determined. PI was measured as the average number of pods to obtain $1 \mathrm{~kg}$ of dry cocoa, and the bean index as the average weight of grain in grams, taken from a sample of 100 dry cocoa beans.

Statistical analysis. Each of the recorded variables was analyzed by analysis of variance (ANOVA), followed by a Tukey test at $5 \%$ level, to carry out all the pairwise comparisons between treatments. The Agricolae package (De Mendiburu, 2013), included in the $\mathrm{R}$ statistical environment software (R Core Team, 2017), was used

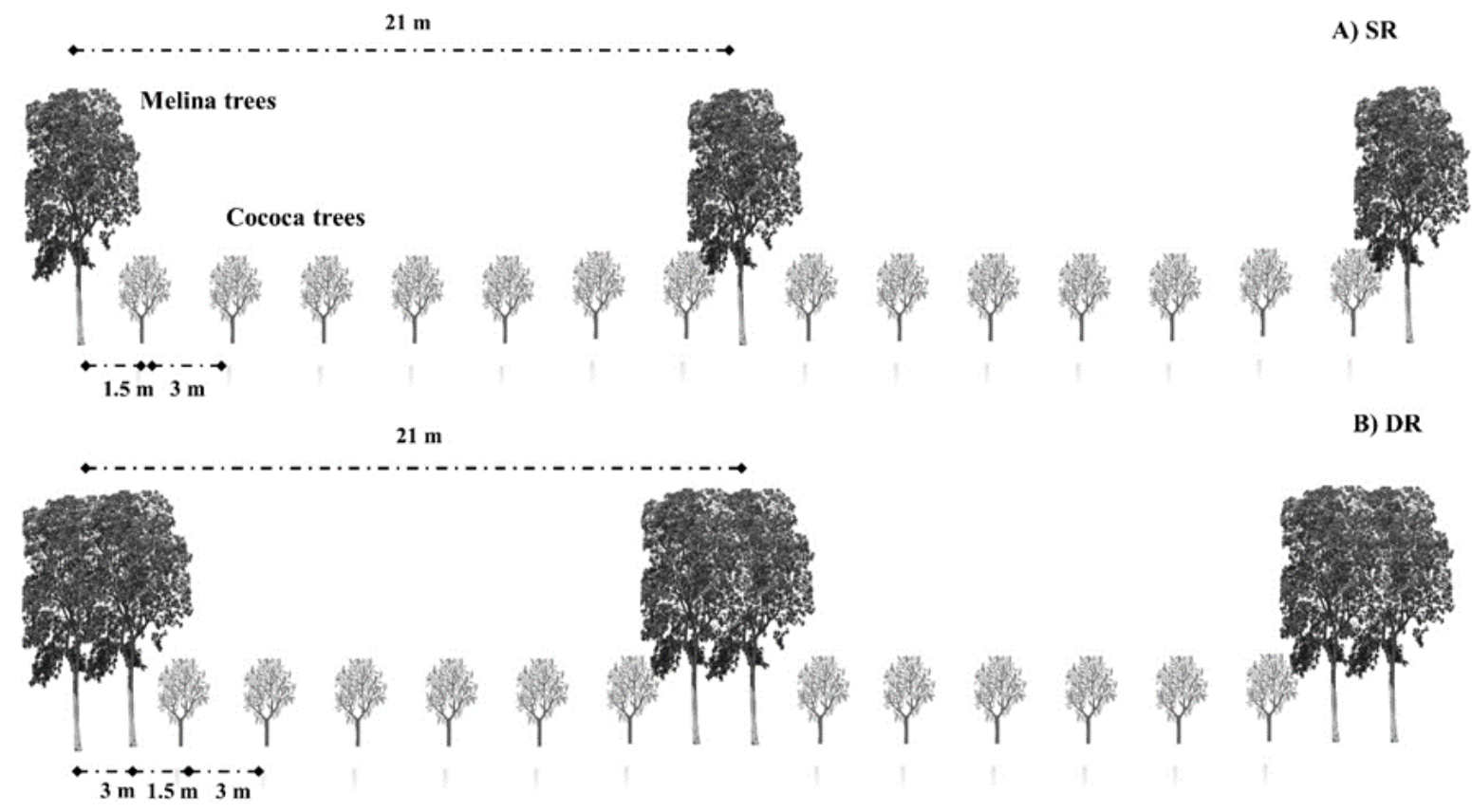

Figure 2. Transversal view of the design of evaluation plots. A) Single Row (SR) and B) Double Row (DR) with trees of the forest species Gmelina arborea

\section{RESULTS AND DISCUSSION}

Since the evaluated cocoa clones presented different behavior regarding the start of production, an analysis was carried out separating cocoa cultivars called early clones such as CCN51 and TSH565, where cocoa yield data were recorded from the first production cycle (2014), and late clones such as ICS60 and ICS95, which started production in the second year (2015) of evaluation.

For the variable dry cocoa production of early clones in year 1 (2014), there were significant effects $(P=0.0007)$ of the clone factor. On the contrary, the habitat, pruning factors, and the interactions $\mathrm{HxP}$ and $\mathrm{HxC}$ did not present significant effects $(P>0.05)$. Table 1 shows the mean values of dry cocoa production for the different $\mathrm{H}, \mathrm{P}$, and $\mathrm{C}$ combinations. For year 1 , cocoa clone TSH565 was four times superior to clone CCN51.

In the first year of evaluation, the cocoa dry grain production was characterized by two materials' premature responses (TSH565 and CCN51). For the life zone in which the experiment was carried out, earlier materials showed the first flowering at 14 months after grafting (MAG), the first pods at $17 \mathrm{MAG}$, and the first harvest at $21 \mathrm{MAG}$.

The compatibility design, in this case, 
positively influenced yield response of clone TSH565, which presented a higher production compared to clone CCN51, which is considered one of the materials with the highest production potential due to its genetic characteristics. It is noted that the clone TSH565 is a selfincompatible material, while the CCN51 is a selfcompatible material (Cadavid, 2011).

Table 1. Mean values of early clones dry cocoa production $\left(\mathrm{kg} \mathrm{ha}^{-1}\right)$ in year 1 (2014), for the combination of habitat x pruning x clone. EA Cotové. Universidad Nacional de Colombia. Santa Fe de Antioquia, Colombia

\begin{tabular}{|c|c|c|c|c|}
\hline \multirow{2}{*}{ Habitat } & \multirow{2}{*}{ Pruning } & \multicolumn{2}{|c|}{ Clone } & \multirow{2}{*}{ Mean (Pruning) } \\
\hline & & CCN51 & TSH565 & \\
\hline \multirow{2}{*}{ SR } & OG & 24.07 & 121.29 & 72.68 \\
\hline & PG & 34.99 & 120.31 & 77.65 \\
\hline \multicolumn{2}{|c|}{ Mean SR } & 29.53 & 120.8 & 75.17 \\
\hline \multirow{2}{*}{ DR } & OG & 15.95 & 55.06 & 35.51 \\
\hline & PG & 24.75 & 120.08 & 72.42 \\
\hline \multicolumn{2}{|c|}{ Mean DR } & 20.35 & 87.57 & 53.96 \\
\hline \multicolumn{2}{|c|}{ Mean (Clone) } & $24.94 \mathrm{~b}$ & $104.18 \mathrm{a}$ & 64.56 \\
\hline
\end{tabular}

SR: single row, DR (double row), OG (orthotropic growth stimulus), and PG (plagiotropic growth stimulus). According to Tukey's HSD test, letters in the same row indicate a nonsignificant statistical difference at the $5 \%$ level

Besides, there is inter-compatibility between these materials higher than the $70 \%$ mentioned by Aránzazu et al. (2009), which positively influenced the response of TSH565. Mora et al. (2011) report a lower yield of self-incompatible clones, however, despite the above, the CCN51 material outperformed TSH565, which differs from our results for the first year of evaluation. According to Lahive et al. (2019), prolonged soil water limitation can cause a large decrease in cocoa yield. Rainfall has been reported to be beneficial to yield in the flowering and initial stages of pod development, but becomes less influential in later stages, and can even prevent pods for reaching complete maturity. In this sense, the water deficit can affect flowering and the compatibility between clones by reducing flower formation and pollen viability, reducing fruit set and formation.

For dry cocoa production of early clones in year 2 (2015) there were nonsignificant effects $(P=0.094)$ of the clone factor, and neither the other factors, nor the interactions, showed significant effects as well $(P>0.05)$. For this year, the clone TSH565 tended to be the most productive material like in the first year; however, it did not show significant differences with the CCN51 clone (Table 2).

For the late clones, the beginning of production of dry cocoa in year 2 was recorded in ICS60 and ICS95, and it was observed that yields were significantly lower than those obtained in clones TSH565 and CCN51. Even so, being the ICS60 material a self-incompatible genotype, it did not differ significantly from the ICS95 clone, which is self-compatible (Table 3). It is noteworthy that ICS60 and ICS95 clones did not start their production during the first production cycle for the evaluated life zone, thus confirming that they are late materials in tropical dry forests.

As indicated, the behavior of the selfincompatible materials (TSH565 and ICS60) stands out, although did not differ significantly from the self-compatible materials CCN51 and ICS95, respectively. The above can be explained due to the compatibility arrangement established in the plantation, conserving inter-compatibility greater than $70 \%$ between CCN51 and TSH565; this plantation design favored TSH565 in the first year. However, the rise in production of CCN51 for the second year increased the yield by seven times, going from $24.94 \mathrm{~kg} \cdot \mathrm{ha}^{-1}$ of dry cocoa to $169.25 \mathrm{~kg} \cdot \mathrm{ha}^{-1}$; on the other hand, TSH565 had an increase of more than double, from 104.18 to $244.77 \mathrm{~kg} \cdot \mathrm{ha}^{-1} \cdot$ year $^{-1}$ of dry cocoa.

In early clones combined production (2014$2015)$, there was a significant effect $(P=0.009)$ of clones, while neither the other factors nor the 
interactions showed significant effect $(P>0.05)$. As observed in Table 4, for the total production of the two years, the same behavior observed in the second year was presented. The clones TSH565 and CCN51 did not differ significantly in the production of dry grain accumulated for the two years of evaluation. The same happened for the ICS60, and ICS95 clones, which did not present differences, and the yield achieved was likewise observed in year two. As mentioned, these clones did not produce any yield in the first year.

Table 2. Mean values of early clones dry cocoa production $\left(\mathrm{kg} \cdot \mathrm{ha}^{-1}\right)$ in year 2 (2015), for the combination of habitat x pruning x clone. EA Cotové. Universidad Nacional de Colombia. Santa Fe de Antioquia, Colombia

\begin{tabular}{cccccc}
\hline \multirow{2}{*}{ Habitat } & \multirow{2}{*}{ Pruning } & \multicolumn{3}{c}{ Clone } & \multirow{2}{*}{ Mean (Pruning) } \\
\cline { 3 - 5 } \multirow{2}{*}{ SR } & & OG & 126.48 & TSH565 & 126.48 \\
& & PG & 173.95 & 93.61 & 173.95 \\
\hline \multirow{2}{*}{ Mean SR } & & 150.21 & 253.24 & 211.82 \\
\hline \multirow{2}{*}{ DR } & & OG & 285.71 & 273.42 & 244.20 \\
& & PG & 90.87 & 202.69 & 160.21 \\
\hline \multicolumn{2}{c}{ Mean DR } & 188.29 & 216.12 & 202.21 \\
\hline \multicolumn{2}{c}{ Mean (Clone) } & 169.25 a & $244.77 \mathrm{a}$ & 207.01 \\
\hline
\end{tabular}

SR: single row, DR (double row), OG (orthotropic growth stimulus), and PG (plagiotropic growth stimulus). According to Tukey's HSD test, letters in the same row indicate a nonsignificant statistical difference at the $5 \%$ level.

Table 3. Mean values of late clones dry cocoa production $\left(\mathrm{kg} \cdot \mathrm{ha}^{-1}\right)$ in year $2(2015)$, for the combination habitat x pruning x clone. EA Cotové. Universidad Nacional de Colombia. Santa Fe de Antioquia, Colombia

\begin{tabular}{|c|c|c|c|c|}
\hline \multirow{2}{*}{ Habitat } & \multirow{2}{*}{ Pruning } & \multicolumn{2}{|c|}{ Clone } & \multirow{2}{*}{ Mean (Pruning) } \\
\hline & & ICS60 & ICS95 & \\
\hline \multirow{2}{*}{ SR } & OG & 5.61 & 9.02 & 7.32 \\
\hline & PG & 60.61 & 9.72 & 35.17 \\
\hline \multicolumn{2}{|c|}{ Mean SR } & 33.11 & 9.37 & 21.24 \\
\hline \multirow{2}{*}{ DR } & $\overline{\mathrm{OG}}$ & 47.11 & 0 & 23.56 \\
\hline & PG & 36.08 & 24.81 & 30.45 \\
\hline \multicolumn{2}{|c|}{ Mean DR } & 41.59 & 12.04 & 26.82 \\
\hline \multicolumn{2}{|c|}{ Mean (Clone) } & $37.35 \mathrm{a}$ & $10.88 \mathrm{a}$ & 24.12 \\
\hline
\end{tabular}

SR: single row, DR (double row), OG (orthotropic growth stimulus), and PG (plagiotropic growth stimulus). According to Tukey's HSD test, letters in the same row indicate a nonsignificant statistical difference at the $5 \%$ level.

At year 2015, the average yields of CCN51 and TSH565 showed to be higher than those of ICS60 and ICS95 clones (Tables 2 and 3); although in that year there were no statistical differences between the CCN51 and TSH565 materials, it is important to highlight that the production of a self-incompatible material (TSH565) tended to predominate over the self-compatible material (CCN51). This is best observed in the evaluation of the two years of production (Table 4), and one of the probable reasons is the inter-compatibility of TSH565 with several of the genetic materials used in the present investigation, specifically CCN51 and ICS95.

In cocoa, growth and development are highly dependent on temperature; however, although greater growth has been described with increasing temperature (Lahive et al., 2019), reproductive development, in general, is more sensitive to temperature than vegetative development (Almeida and Valle, 2007; Bita and Gerats, 2013). According to Lahive et al. (2019), the minimum 
and maximum temperatures recorded in the various cocoa-producing countries worldwide vary between $18-24{ }^{\circ} \mathrm{C}$ and $26-34{ }^{\circ} \mathrm{C}$, so that cocoa plants can adapt to a wide thermal range. In the tropical dry forest, during the experiment's development, the minimum and maximum temperatures varied from $26-28{ }^{\circ} \mathrm{C}$ to $27-32{ }^{\circ} \mathrm{C}$, respectively. This indicates that, from the thermal point of view, the TDF presents favorable temperatures for crop development, not only in growth but also at the reproductive and productive levels; in this sense, it has been shown that pollen flow in cocoa increases with temperature, being highest at $32{ }^{\circ} \mathrm{C}$ (Mena et al., 2020).

Table 4. Total early clones dry cocoa production $\left(\mathrm{kg} \cdot \mathrm{ha}^{-1}\right)$ for two years (2014 -2015), for the combination habitat x pruning x clone. EA Cotové. Universidad Nacional de Colombia. Santa Fe de Antioquia, Colombia

\begin{tabular}{|c|c|c|c|c|}
\hline \multirow{2}{*}{ Habitat } & \multirow{2}{*}{ Pruning } & \multicolumn{2}{|c|}{ Clone } & \multirow{2}{*}{ Mean (Pruning) } \\
\hline & & CCN51 & TSH565 & \\
\hline \multirow{2}{*}{ SR } & $\overline{\mathrm{OG}}$ & 150.55 & 414.90 & 282.73 \\
\hline & PG & 208.93 & 373.55 & 291.24 \\
\hline \multicolumn{2}{|c|}{ Mean SR } & 179.74 & 394.22 & 286.98 \\
\hline \multirow{2}{*}{ DR } & $\mathrm{OG}$ & 301.67 & 257.75 & 279.71 \\
\hline & PG & 115.63 & 349.63 & 232.63 \\
\hline \multicolumn{2}{|c|}{ Mean DR } & 208.65 & 303.69 & 256.17 \\
\hline \multicolumn{2}{|c|}{ Mean (Clone) } & $194.2 \mathrm{~b}$ & $348.95 \mathrm{a}$ & 271.58 \\
\hline
\end{tabular}

SR: single row, DR (double row), OG (orthotropic growth stimulus), and PG (plagiotropic growth stimulus). According to Tukey's HSD test, letters in the same row indicate a nonsignificant statistical difference at the $5 \%$ level

On the other hand, concerning water requirements, the Amazon basin environment, where cocoa plants evolved, is not usually waterlimited $\left(1,300\right.$ to $\left.2,800 \mathrm{~mm} \cdot \mathrm{year}^{-1}\right)$. Many of the cocoa's physiological and morphological characteristics are not suitable for facing water limitations (Lahive et al., 2019). Thus, rainfall distribution throughout the year is also essential since the drought has a negative effect. Three consecutive months with less than $100 \mathrm{~mm}$ of total precipitation result in lower cocoa yields and lower long-term vitality of cocoa trees (Läderach et al., 2013). During the present investigation, a total of $611 \mathrm{~mm}$ was recorded between December 2013 and July 2015, quantity that is below the crop water requirements. According to García and Moreno (2016), cocoa is considered a hydroperiod crop, so precipitation plays an essential role in the grain yield potential due to water impacts growth, leaf emission, photosynthetic activity, and stomatal behavior. While cocoa has been described as particularly sensitive to water deficit, mature trees appear to be less sensitive than seedlings in the field, probably due to the greater availability of resources in the older trees (Läderach et al., 2013). A research carried out by Gateau et al. (2018) demonstrated that water stress in cocoa cultivation could generate up to $15 \%$ mortality in trees and severely reduce crop yield by up to $89 \%$. Thus, in dry and warm environments such as TDF, the cocoa trees can consume large volumes of water due to the higher temperature and solar energy available, increasing the plants' evapotranspiration rate in the form of a more significant deficit in vapor pressure. In the present research, clones CCN51 and TSH565 were subjected to water conditions considered deficient during their first two productive years. They produced up to $348.95 \mathrm{~kg} \cdot \mathrm{ha}^{-1}$ of dry cocoa beans (Table 4). Although these yields can be considered low compared to the productive potential of CCN51 $\left(\sim 1,200 \mathrm{~kg} \cdot \mathrm{ha}^{-1}\right)$ and TSH565 $(\sim 1,440$ $\left.\mathrm{kg} \cdot \mathrm{ha}^{-1}\right)$, stands out their closeness to the national average, which has gone from $406 \mathrm{~kg} \cdot \mathrm{ha}^{-1}$ in 1990 to $360 \mathrm{~kg} \cdot \mathrm{ha}^{-1}$ in 2018 (FAO, 2020). This can be regarded as attractive for the agroecological conditions of the TDF (high temperatures and low rainfall), which is supposed to be favored by establishing this crop in a cocoa-melina agroforestry system. Due to cocoa is expected to be vulnerable to climate change, AFS is considered to improve the sustainability of cocoa production because AFS contributed to climate change mitigation by lowering mean temperatures 
and buffering temperature extremes (Niether et al., 2020). In addition to the above, the use of irrigation is the option to make it viable to grow in areas with water deficit conditions; according to Lahive et al. (2019), keeping the soil at field capacity through supplementary irrigation increased by $40 \%$ the cocoa pod yield during a severe dry season.

Agroforestry systems are an alternative for the management of tropical dry forest areas on intervened or degrading slopes. Its benefits are based on the efficient use of resources, productivity, and food security of rural communities (Mazo et al., 2016). The increase in cocoa yield occurs by making better use of available resources when trees are used in agroforestry systems. Trees and crops must capture a greater proportion of available resources, mostly water, and use them more efficiently to produce dry matter (Soni et al., 2017). According to Schwendenmann et al. (2010), shade trees use more water from the soil deeper layers, while cocoa extracts shallow water. Thus, the AFS increases soil water availability, allowing trees to acquire water from the surface soil, between 9.4 and $24.3 \%$ according to Yang et al. (2020). Schroth et al. (2016) stated that climate change could induce a significant decrease in the areas suitable for cocoa cultivation due to the water deficit. So cocoa plants have also received particular attention as a possible climate-smart crop, since it has been cultivated long ago as part of an AFS that provides additional benefits by improving biodiversity and ecosystem services (Vaast and Somarriba, 2014).

Yield components. Regarding the pod index (PI) variable, there were significant effects of clone $P=0.0144)$ and the PxC interaction $(P=0.0242)$. Neither of the other effects was significant $(P>0.05)$. Table 5 shows the cocoa PI variable's mean values for the pruning $\mathrm{x}$ clone combinations. There were no differences between the clones in response to the orthotropic growth stimulus (OG), with a mean PI of 24.4. Regarding the plagiotropic growth stimulus (PG), the clones showed significant differences for PI. Clone ICS95 was the one with the highest PI, requiring almost $50 \%$ more pods to generate one kilogram of dry cocoa than clones TSH565 and ICS60, which did not differ from each other. The best pod index was presented in clone CCN51, which requires $75 \%$ fewer pods than ICS95 and about $25 \%$ fewer pods than clones TSH565 and ICS60 to obtain one kilogram of dry cocoa.

Table 5. Mean values of the cocoa pod index (PI) for the interaction pruning $\mathrm{x}$ clone. EA Cotové. Universidad Nacional de Colombia. Santa Fe de Antioquia, Colombia. 2015

\begin{tabular}{|c|c|c|c|c|c|}
\hline \multirow{2}{*}{ Pruning } & \multicolumn{4}{|c|}{ Clone } & \multirow{2}{*}{ Mean (Pruning) } \\
\hline & CCN51 & TSH565 & ICS60 & ICS95 & \\
\hline OG & $25 \mathrm{aA}$ & $25.5 \mathrm{aA}$ & 23 aA & $24 \mathrm{aB}$ & 24.4 \\
\hline PG & $20 \mathrm{cB}$ & $25.5 \mathrm{bA}$ & $24.5 \mathrm{bA}$ & $35 \mathrm{aA}$ & 26.3 \\
\hline Mean (Clone) & 22.5 & 25.5 & 24 & 29.5 & 25.35 \\
\hline
\end{tabular}

OG (orthotropic growth stimulus) and PG (plagiotropic growth stimulus). According to Tukey's HSD test, equal lowercase letters in the same row and equal upper-case letters in the same column indicate nonsignificant statistical difference at the $5 \%$ level.

Regarding the clone factor, the mean values of CCN51, TSH565, and ICS60 were very similar, and showed to be lower than that of the ICS95 clone, which would require the largest number of pods to produce one kilogram of dry cocoa (Table $5)$.

On the other hand, the CCN51 clone varied in response to the growth stimulus, presenting a lower cocoa pod index $(20 \%)$ in the plagiotropic than the orthotropic pruning. In contrast, the ICS95 clone showed a higher PI in plagiotropic pruning. TSH565 and ICS60 clones did not differ in response to orthotropic and plagiotropic stimuli.

It is important to bear in mind that each material or clone has different genetic characteristics. In general terms, the ICS95 clone is the genetic material that requires the greatest number of pods to achieve one dry bean kilogram. According to Aránzazu et al. (2009), average values for cocoa pod index were established for CCN51 (16), TSH565 (20), ICS95 (19), and ICS60 (14). In this case, the PI values reported for 
each of the materials evaluated differ in this investigation. This difference may be related to the environmental supply, since the tropical dry forest is a region characterized by low water supply with about $1,100 \mathrm{~mm}$ per year, a precipitation regime well below the requirements of the crop, which are of the order of $2,000 \mathrm{~mm}$ per year (Fedecacao, 2012). Therefore, as a physiological strategy, the different clones evaluated tended to produce a greater number of cobs, although with a lower weight of seeds, that guarantee reproductive structures' production.

Pod index values reported and consistent with those found in this research are those indicated by Quintana et al. (2015), who in the municipality of San Vicente de Chucuri, Santander, Colombia, reported similar values for CCN51 (PI=17) and ICS60 (PI=18). However, in this region with altitudes between 200 and 1200 meters, the average rainfall is around 1,500 $\mathrm{mm}$ per year. For the ICS95, a PI of 26 was reported; in this case, the ICS95 obtained similar values, and it was also the material that had the highest PI.

For the bean index (BI) variable, significant differences $(P=0.00016)$ were evidenced for the clone factor $(C)$. Neither the other factors nor the interactions showed significant effects $(P>0.05)$ for the BI.

Table 6 shows the mean values of the BI for the habitat $\mathrm{x}$ pruning $\mathrm{x}$ clone combinations. As can be observed, the clones CCN51, TSH565, and ICS60 did not present significant differences among them but were statistically superior to the ICS95 clone, which presented about $20 \%$ less weight for each cocoa bean, which indicates that the grains of clone ICS95 haver less weight than those of the other materials. The above added that this clone had the highest pod index (29.5) and the lowest production $\left(10.88 \mathrm{~kg} \cdot \mathrm{ha}^{-1}\right)$, indicating that ICS95 is not a clone with potential cocoa production in dry conditions with a low water supply. On the other hand, although the clone ICS60 did not differ for BI concerning TSH565 and CCN51, it presented the lowest yield.

Table 6. Mean values of the cocoa bean index $(\mathrm{BI})$ for the combination habitat $(\mathrm{H}) \mathrm{x}$ pruning $(\mathrm{P}) \mathrm{x}$ clone (C). EA Cotové. Universidad Nacional de Colombia. Santa Fe de Antioquia, Colombia. 2015

\begin{tabular}{|c|c|c|c|c|c|c|}
\hline \multirow{2}{*}{ Habitat } & \multirow{2}{*}{ Pruning } & \multicolumn{4}{|c|}{ Clone } & \multirow{2}{*}{ Mean (Habitat } \\
\hline & & CCN51 & TSH565 & ICS60 & ICS95 & \\
\hline \multirow{2}{*}{$\mathrm{SR}$} & OG & 1.20 & 1.30 & 1.50 & 1.20 & 1.3 \\
\hline & PG & 1.50 & 1.10 & 1.10 & 1.00 & 1.2 \\
\hline \multicolumn{2}{|c|}{ Mean SS } & 1.35 & 1.20 & 1.30 & 1.15 & 1.2 \\
\hline \multirow{2}{*}{ DR } & $\mathrm{OG}$ & 1.20 & 1.20 & 1.30 & 0.0 & 0.9 \\
\hline & PG & 1.50 & 1.40 & 1.30 & 1.10 & 1.3 \\
\hline \multicolumn{2}{|c|}{ Mean DR } & 1.35 & 1.30 & 1.30 & 1.10 & 1.1 \\
\hline \multicolumn{2}{|c|}{ Mean (Clone) } & $1.31 \mathrm{a}$ & $1.27 \mathrm{a}$ & $1.29 \mathrm{a}$ & $1.07 \mathrm{~b}$ & 1.17 \\
\hline
\end{tabular}

SR: single row, DR: double row, OG: orthotropic growth stimulus, and PG: plagiotropic growth stimulus. According to Tukey's HSD test, equal letters in the same row indicate nonsignificant statistical difference at the $5 \%$ level

Reviewing the values of BI obtained during this investigation and comparing with the results of Aránzazu et al. (2009), CCN51, ICS60 and ICS95 showed lower values, while those of TSH565 were similar. When comparing with the results of Quintana (2015), the values in the present research were lower for CCN51 and similar for TSH565, ICS60 and ICS95.

In general, the yield and yield components of the dry cocoa bean observed in the present work are lower than those reported by Perea et al. (2013), who showed an average yield of 1,500 $\mathrm{kg} \cdot \mathrm{ha}^{-1}$ for CCN51 and 1,200 kg. ha ${ }^{-1}$ for TSH565, and estimated 1,000 and $900 \mathrm{~kg} \cdot \mathrm{ha}^{-1}$ for ICS60 and ICS95, respectively.

\section{CONCLUSIONS}

The TSH 565 and CCN 51 clones were the earliest and most productive materials. ICS 60 and ICS 95 are clones with a low productive response in tropical dry forest conditions. For the pod index and bean index yield components, the CCN51 and TSH 565 clones were highlighted; however, these 
parameters were affected for all the clones evaluated in the TDF conditions. The habitat and pruning factors, and the interactions $\mathrm{H} \times \mathrm{P}$ and $\mathrm{H}$ $\mathrm{x} C$, did not significantly affect cocoa yield and yield components.

\section{ACKNOWLEDGEMENTS}

This publication is derived from the results and information obtained in the development of the project Evaluation of different agroforestry arrangements with cocoa in the TDF, with emphasis on the management of the canopy of the plant community and its effect on production and carbon sequestration, executed by the Universidad Nacional de Colombia, Sede Medellin. We thank the Laboratorio de Ecofisiología de Plantaciones en el Trópico, Departamento de Ciencias Agronómicas, Universidad Nacional de Colombia for its support by Eco physiological instruments

\section{LITERATURE CITED}

1. Almeida, A.F. and R.R. Valle. 2007. Ecophysiology of the cacao tree. Brazilian Journal of Plant Physiology 19(4): 425-448.

2. Aránzazu, F., N. Martínez, D. Guarín, and G. Palencia. 2009. Materiales de cacao en Colombia, su compatibilidad sexual y Modelos de siembra. Unión temporal de cacao de Colombia uno, FedecacaoCorpoica. Bucaramanga. 8, 9, $10 \mathrm{p}$.

3. Bita, C.E. and T. Gerats. 2013. Plant tolerance to high temperature in a changing environment: scientific fundamentals and production of heat stress-tolerant crops. Front Plant Sci 4:273.

4. Cadavid-Vélez, S. 2011. Características de compatibilidad sexual de algunos clones de cacao y su aplicación en siembras comerciales. Compañía Nacional de Chocolates. 28 p. https://n9.cl/8y2qh (retrieved Oct. 2021)

5. Ceccarelli, V., T. Fremout, D. Zavaleta, S. Lastra, S. Imán Correa, E. Arévalo-Gardini et al. 2021. Climate change impact on cultivated and wild cacao in Peru and the search of climate change-tolerant genotypes. Divers Distrib. 2021,00: 1-15.

6. Cilas, C. and P. Bastide. 2020. Challenges to cocoa production in the face of climate change and the spread of pests and diseases. Agronomy 10: 1232.

7. De Mendiburu, F. 2013. Agricolae: Statistical Procedures for Agricultural Research. R package version 1.1-4. In: The Comprehensive R Archive Network. 155 p. https://n9.cl/zr7jc (retrieved Oct. 2021).

8. FAO (Organización Mundial para la Alimentación y la Agricultura). 2010. "Climate-Smart" Agriculture. Policies, Practices and Financing for Food Security, Adaptation and Mitigation. FAO, Rome. https://n9.cl/ppybw (retrieved Oct. 2021).

9. FAO (Organización Mundial para la Alimentación y la Agricultura). 2020. FAOSTAT Online Database. FAO, Rome. https://n9.cl/dyh1h (retrieved on Mar. 2020).

10. FEDECACAO (Federación Colombiana de Cacaoteros). 2012. Guía técnica para el cultivo del cacao. $5^{\circ}$ edición. Ediciones LCB. Bogotá.

11. Fernández, M. 2013. Efectos del cambio climático en la producción y rendimientos de cultivos por sectores. Fondo financiero de proyectos de desarrollo-Fonade e Instituto de Hidrología, Meteorología y Estudios Ambientales-IDEAM. 6 p.

12. García, J.L. and L.P.F. Moreno. 2016. Respuestas fisiológicas de Theobroma cacao L. en etapa de vivero a la disponibilidad de agua en el suelo. Acta Agronómica 65(1): 44-50.

13. Gateau-Rey, L., E. Tanner, B, Rapidel, J. Marelli, and S. Royaert. 2018. Climate change could threaten cocoa production: Effects of 2015-16 El Niño-related drought on cocoa agroforests in Bahia, Brazil. PloS One 13(7): e0200454.

14. IDEAM (Instituto de Hidrología, Meteorología y Estudios Ambientales). 2020. Datos Hidrometeorológicos. Bogotá. https://n9.cl/r7z3a (retrieved Dec. 2020).

15. Läderach P., A. Martinez-Valle, G. Schroth and N. Castro. 2013. Predicting the future climatic suitability for cocoa farming of the world's leading producer countries, Ghana and Côte d'Ivoire. ClimChang 119(3-4): 841-854. 
16. Lahive, F., P. Hadley and A.J. Daymond. 2019. The physiological responses of cacao to the environment and the implications for climate change resilience. A review. Agronomy for Sustainable Development, 39(1): Article 5.

17. Mazo, D.L.A., J.E. Rubiano, and A. Castro. 2016. Sistemas agroforestales como estrategia para el manejo de ecosistemas de Bosque seco Tropical en el suroccidente colombiano utilizando los SIG. Cuadernos de Geografía: Revista Colombiana de Geografía, 25(1): 65-77.

18. Mena-Montoya, M., L.C. García-Cruzatty, E. Cuenca-Cuenca, L.D. Vera-Pinargote, R. Villamar-Torres and S. Mehdi-Jazayeri. 2020. Pollen flow of Theobroma cacao and its relationship with climatic factors in the central zone of the Ecuadorian Littoral. Bioagro 32(1): 39-48.

19. Mora, R.J., O.H. Burbano and P.W. Ballesteros. 2011. Efecto de la fertilización con diversas fuentes sobre el rendimiento de cacao. Rev. Cien. Agríc. 28(2):81-94.

20. Montagnini F., E. Somarriba, E. Murgueitio, H. Fassola and B. Eibl. 2015. Sistemas Agroforestales. Funciones Productivas, Socioeconómicas y Ambientales. Serie técnica. Informe técnico 402. CATIE, Turrialba, Costa Rica. Editorial CIPAV, Cali, Colombia. 454 p.

21. Montoya, I., L. Montoya and P. Lowy. 2015. Oportunidades para la actividad cacaotera en el municipio de Tumaco, Nariño, Colombia. Entramado 11(1): 48-59.

22. Niether W., L. Armengot, C. Andres, M. Schneider, and G. Gerold. 2018. Shade trees and tree pruning alter throughfall and microclimate in cocoa (Theobroma cacao L.) production systems. Annals of Forest Science 75(2): 38.

23. Niether W., J. Jacobi, W. Blaser, C. Andres, and L. Armengot. 2020. Cocoa agroforestry systems versus monocultures: a multidimensional meta-analysis. Environmental Research Letters 15(10):104085.

24. Pabón-Caicedo J.D. and J.C. AlarcónHincapié. 2016. El efecto del cambio climático sobre las zonas áridas y semiáridas de Colombia. Intercard/Intergis-UDC (en ruso) 22: 56-62.

25. Perea V.A., G.N. Martínez, H.F. Aránzazu and C.T. Cadena. 2013. Características de calidad del cacao de Colombia-Catálogo de 26 cultivares. Fedecacao, Bogotá. 107 p.

26. Quintana, L. F. F., S. Casteblanco, A. Jérez, and N. Guerrero. 2015. Caracterización de tres índices de cosecha de cacao de los clones CCN 51, ICS 60 e ICS 95, en la montaña santandereana, Colombia. Revista de Investigación Agraria y Ambiental 6: 259-262.

27. R Core Team. 2017. A Language and Environment for Statistical Computing. In: $\mathrm{R}$ Foundation for Statistical Computing. 2673 p. https://n9.cl/0gsyd (retrieved on Jan. 2020).

28. Schroth G., P. Laderach, J. Dempewolf, S. Philpott, J. Haggar, H. Eakin, T. Castillejos, M.J. Garcia, P.L. Soto, R. Hernandez, A. Eitzinger and J. Ramirez-Villegas. 2009. Towards a climate change adaptation strategy for coffee communities and ecosystems in the Sierra Madre de Chiapas, Mexico. Mitigation and Adaptation Strategies for Global Change 14: 605-625.

29. Schroth, G., P. Läderach, A.I. MartinezValle, C. Christian Bunn and L. Jassogne. 2016. Vulnerability to climate change of cocoa in West Africa: Patterns, opportunities and limits to adaptation. Sci. Total Environ. 556: 231-241.

30. Schwendenmann L., E. Veldkamp, G. Moser, D. Hölscher, M. Köhler, Y. Clough, et al. 2010. Effects of an experimental drought on the functioning of a cacao agroforestry system, Sulawesi, Indonesia. Glob. Change Biol. 16: 1515-1530.

31. Soni, M. L., V. Subbulakshmi, K.R. Sheetal, N.D. Yadava, and J.C. Dagar. 2017. Agroforestry for increasing farm productivity in water-stressed ecologies. In: J.C. Dagar and V.P. Tewari (eds.). Agroforestry. Springer, Singapore. pp. 369411.

32. Vaast, P. and E. Somarriba. 2014. Trade-offs between crop intensification and ecosystem services: The role of agroforestry in cocoa 
cultivation. Agroforestry Systems 88: 94756.

33. Yang, B., X. Meng, A.K. Singh, P. Wang, L. Song, S. Zakari, and W. Liu. 2020.
Intercrops improve surface water availability in rubber-based agroforestry systems. Agriculture, Ecosystems \& Environment 298: 106937. 